\title{
Implementasi Metode Case-Based Reasoning, Dempster-Shafer, dan Teorema Bayes pada Sistem Pakar Identifikasi Hama dan Penyakit Tanaman Manggis
}

\author{
Implementation of Case-Base Reasoning, Dempster Shafer, and \\ Bayes Theorem Methods on Expert System for Identification of \\ Pests and Diseases of Mangosteen
}

\author{
FARHA FITRAHUL JANAH ${ }^{1 *}$, MEITA ARIFANY $^{1}$, SITI AISYAH $^{1}$, FREZA RIANA $^{1}$
}

\begin{abstract}
Abstrak
Manggis mempunyai prospek tinggi dalam skala agribisnis. Berdasarkan data ekspor komoditas pertanian sub sektor hortikultura (buah-buahan segar), manggis berada pada peringkat ke-1 pada tahun 2020. Kendala budidaya manggis adalah rendahnya kualitas buah yang tidak layak ekspor yang disebabkan oleh serangan hama dan penyakit. Umumnya, upaya para petani manggis saat menghadapi masalah tersebut adalah berkonsultasi dengan seorang pakar. Namun, ketersediaan dan kehadiran pakar dalam suatu daerah masih sangat terbatas. Sistem pakar menjadi solusi untuk mengidentifikasi hama dan penyakit pada tanaman manggis secara cepat. Sistem pakar dihadirkan sebagai salah satu cara untuk memecahkan permasalahan setelah seorang pakar. Metode Case-Based Reasoning, Dempster-Shafer, dan Teorema Bayes merupakan metode yang dapat digunakan pada sistem pakar. Penelitian ini bertujuan untuk membangun sistem pakar berbasis website dalam mengidentifikasi hama dan penyakit yang menyerang tanaman manggis berdasarkan gejala-gejala. Ketiga metode tersebut diterapkan performanya dengan melihat nilai akurasinya. Nilai akurasi didapatkan dari perbandingan hasil jawaban sistem per tiap metode dengan hasil pakar. Dari 30 uji data yang dilakukan secara acak, hasil penelitian ini menunjukkan nilai akurasi yang sama untuk Case-Based Reasoning dan Dempster-Shafer, yaitu sebesar 93\%, dan Teorema Bayes sebesar $90 \%$. Sistem Pakar yang telah dibangun dapat digunakan oleh petani untuk mengidentifikasi hama dan penyakit pada tanaman manggis.
\end{abstract}

Kata kunci: Case-Based Reasoning, Dempster-Shafer, Sistem Pakar, Teorema Bayes

\begin{abstract}
Mangosteen has high prospects on the agribusiness scale. The obstacle to mangosteen cultivation is the low quality of fruit that is not suitable for export caused by pests and diseases. Generally, the effort of mangosteen farmers when facing this problem is to consult an expert. However, the availability and presence of experts in an area are very limited. An expert system is a solution to quickly identify pests and diseases on mangosteen plants. Expert systems are presented as a way to solve problems after an expert. Case-Based Reasoning, Dempster-Shafer, and Bayes theorem are methods that can be used in expert systems. This study aims to build a-based expert system website in identifying pests and diseases that attack mangosteen plants based on symptoms. The performance of the three methods will be compared by looking at the accuracy value. The accuracy value is obtained from the comparison of the system's answer results per each method with expert results. From 30 data tests, the results of this study show the same accuracy value for Case-Based Reasoning and Dempster-Shafer is 93\% and Bayes is 90\%. The Expert System that has been built can be used by farmers to identify pests and diseases on mangosteen plants.
\end{abstract}

Keywords: Bayes' Theorem, Case-Based Reasoning, Dempster-Shafer, Expert System

${ }^{1}$ Program Studi Teknik Informatika, Fakultas Teknik dan Sains, Universitas Ibn Khaldun Bogor, Bogor 16162

*Penulis Korespondensi: Telp: 081299407484; Surel: farhafz123@gmail.com 


\section{PENDAHULUAN}

Buah manggis (Garcinia Mangostana Linn) merupakan komoditi hortikultura buahbuahan tropis asli Indonesia yang memiliki prospek ekspor yang cerah serta bernilai ekonomis tinggi. Akan tetapi, tidak semua buah manggis yang diproduksi berkualitas baik. Buah manggis yang berkualitas buruk tidak layak diekspor. Salah satu kendala dalam budidaya manggis adalah rendahnya kualitas buah yang disebabkan oleh adanya serangan hama dan penyakit (Syah 2016). Minimnya pengetahuan para petani manggis terkait adanya serangan hama dan penyakit menyebabkan terlambatnya penanganan terhadap tanaman manggis. Untuk menangani permasalahan tersebut dibutuhkan seseorang yang ahli di bidang hama dan penyakit tanaman manggis untuk memberikan pengetahuan kepada petani manggis. Namun, kehadiran seorang pakar tidak selalu ada pada setiap daerah sehingga diperlukan sistem pakar untuk membantu petani manggis dalam mencegah serangan hama dan penyakit. Tujuan utama sistem pakar bukan untuk menggantikan kedudukan seorang pakar, melainkan memasyarakatkan pengetahuan dan pengalaman seorang pakar (Jasri 2019).

Berdasarkan permasalahan tersebut, penelitian ini bertujuan untuk membangun sebuah Sistem Pakar berbasis web untuk mengidentifikasi hama dan penyakit pada tanaman manggis dengan menggunakan metode Case-Based Reasoning, Dempster-Shafer dan Teorema Bayes. Pengguna akan memilih salah satu dari metode tersebut untuk dapat melakukan proses identifikasi. Metode Case-Base Reasoning, Dempster-Shafer, dan Teorema Bayes dalam sistem pakar telah banyak digunakan untuk mencari solusi masalah yang berkaitan dengan probabilitas, termasuk penerapannya dalam pendeteksian penyakit.

Sistem pakar (expert system) umumnya disebut sebagai knowledge base system, yaitu suatu aplikasi komputer yang ditujukan untuk membantu pengambilan keputusan atau pemecahan persoalan dalam bidang yang spesifik. Sistem ini bekerja dengan menggunakan pengetahuan dan metode analisis yang telah didefinisikan terlebih dahulu oleh seorang pakar yang sesuai dengan bidang keahliannya (Hayadi 2016).

Case-Based Reasoning (CBR) merupakan sebuah pendekatan penyelesaian masalah dengan menekankan pada pengalaman sebelumnya. Metode ini dapat menyelesaikan permasalahan baru dengan memanfaatkan kembali dan melakukan penyesuaian terhadap permasalahan yang memiliki kesamaan dengan yang telah diselesaikan pada permasalahan sebelumnya (Mulyana 2009). Beberapa penelitian yang menggunakan metode Case-Based Reasoning menyatakan bahwa metode ini merupakan metode yang cukup baik dalam mendiagnosis suatu penyakit pada manusia maupun tumbuhan (Saputri et al. 2020). DempsterShafer (D-S) adalah teori matematika dari evidence yang dapat menangani informasi yang tidak pasti, tidak tepat, dan tidak akurat (Wirawan 2017). Teori ini memiliki beberapa karakteristik yang secara institutif sesuai dengan cara berfikir seorang pakar, namun dengan dasar matematika yang kuat (Aldo dan Putra 2020). Teorema Bayes merupakan salah satu metode dalam sistem pakar yang telah banyak digunakan untuk mencari solusi masalah yang berkaitan dengan probabilitas, termasuk penerapannya dalam pendeteksian penyakit. Teorema Bayes adalah suatu metode yang menggunakan probabilitas untuk menghasilkan keputusan dan informasi yang benar berdasarkan penyebab-penyebab yang terjadi (Ramadhan dan Fatimah 2018).

Penelitian ini diharapkan dapat membantu petani dalam melakukan identifikasi, serta memberikan penanganan terhadap serangan hama dan penyakit yang menyerang tanaman manggis sehingga dapat meminimalisir penurunan kualitas buah yang dihasilkan. 


\section{METODE}

\section{Tahapan Penelitian}

Penelitian ini terdiri dari enam tahapan, yaitu pengumpulan data, basis pengetahuan, analisis dan penerapan metode, perancangan, implementasi, dan pengujian. Alur pada tahapan penelitian dapat dilihat pada Gambar 1.

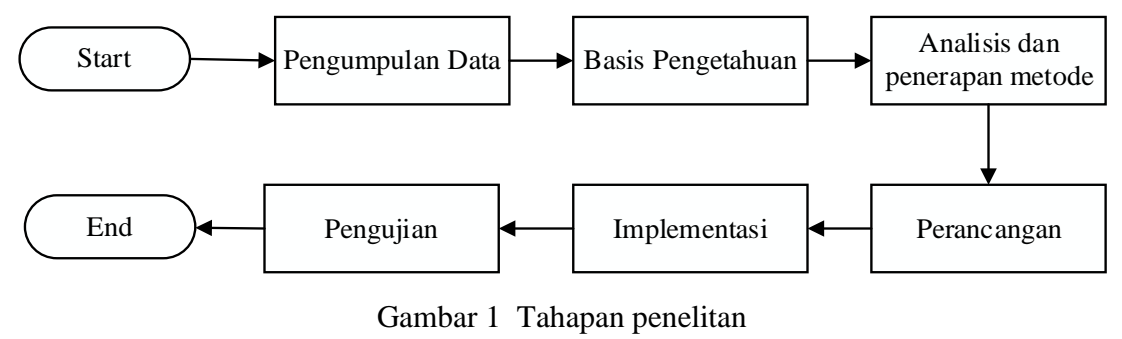

Tahap pengumpulan data dilakukan untuk memudahkan analisis sistem pakar untuk mendiagnosis tanaman manggis. Data yang dikumpulkan pada tahap pengumpulan data adalah berdasarkan hasil studi literatur penelitian terkait serta melakukan wawancara dengan pakar dan petani manggis. Langkah selanjutnya adalah basis pengetahuan. Pada tahap ini dikumpulkan fakta dan aturan mengenai penyakit dan hama tanaman manggis yang divalidasi oleh seorang pakar hama dan penyakit tanaman manggis yang berasal dari Balai Penelitian Buah Tropika, Solok, Sumatera Barat. Setelah basis pengetahuan dibangun, aturan akan dianalisis dan diterapkan ke dalam sistem pakar dengan menggunakan metode Case-Based Reasoning, Dempter-Shafer, dan Teorema Bayes.

Langkah selanjutnya adalah perancangan. Perancangan terdiri dari perancangan basis data dan perancangan antarmuka sistem. Implementasi sistem kemudian dilakukan untuk mengaplikasikan desain dalam bentuk aplikasi sistem pakar berbasis web. Pengujian dilakukan untuk memastikan bahwa sistem memenuhi kebutuhan pengguna. Pada tahap ini juga dilakukan perhitungan akurasi dengan membandingkan hasil diagnosis sistem yang menerapkan metode Case-Based Reasoning, Dempter-Shafer, dan Teorema Bayes dengan hasil diagnosis pakar sebagai acuan.

\section{Metode Case-Based Reasoning}

Gambar 2 mengambarkan algoritma metode Case-Based Reasoning yang digunakan pada penelitian ini.

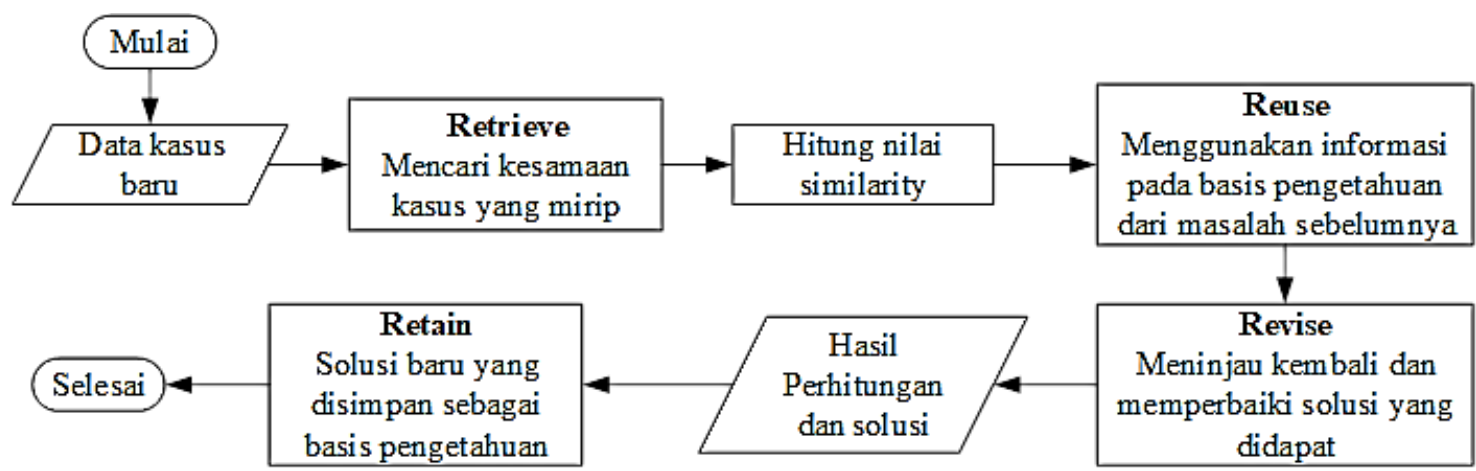

Gambar 2 Algoritme Case-Based Reasoning

CBR sebagai sebuah siklus yang disingkat 4R, yaitu Retrieve (memperoleh kembali), Reuse (menggunakan), Revise (meninjau), dan Retain (menyimpan). Berdasarkan penjelasan tersebut dapat diambil kesimpulan perhitungan pekerjaan metode ini adalah seperti pada Persamaan 1 (Mulyana 2009). 
Keterangan :

$$
\text { Similarity }(\text { problem, case })=\frac{(S 1 \times W 1)+(S 2 \times W 2)+\cdots+(S n \times W n)}{W 1+W 2+\cdots+W n}
$$

$\mathrm{S}=$ Similarity (nilai kemiripan) yaitu 1 (sama) dan 0 (beda).

$\mathrm{W}=$ Weight (bobot yang diberikan).

\section{Metode Dempster-Shafer}

Algoritma perhitungan metode D-S untuk mendiagnosis penyakit dan hama pada tanaman manggis yang digunakan dalam penelitian ini digambarkan pada Gambar 3.

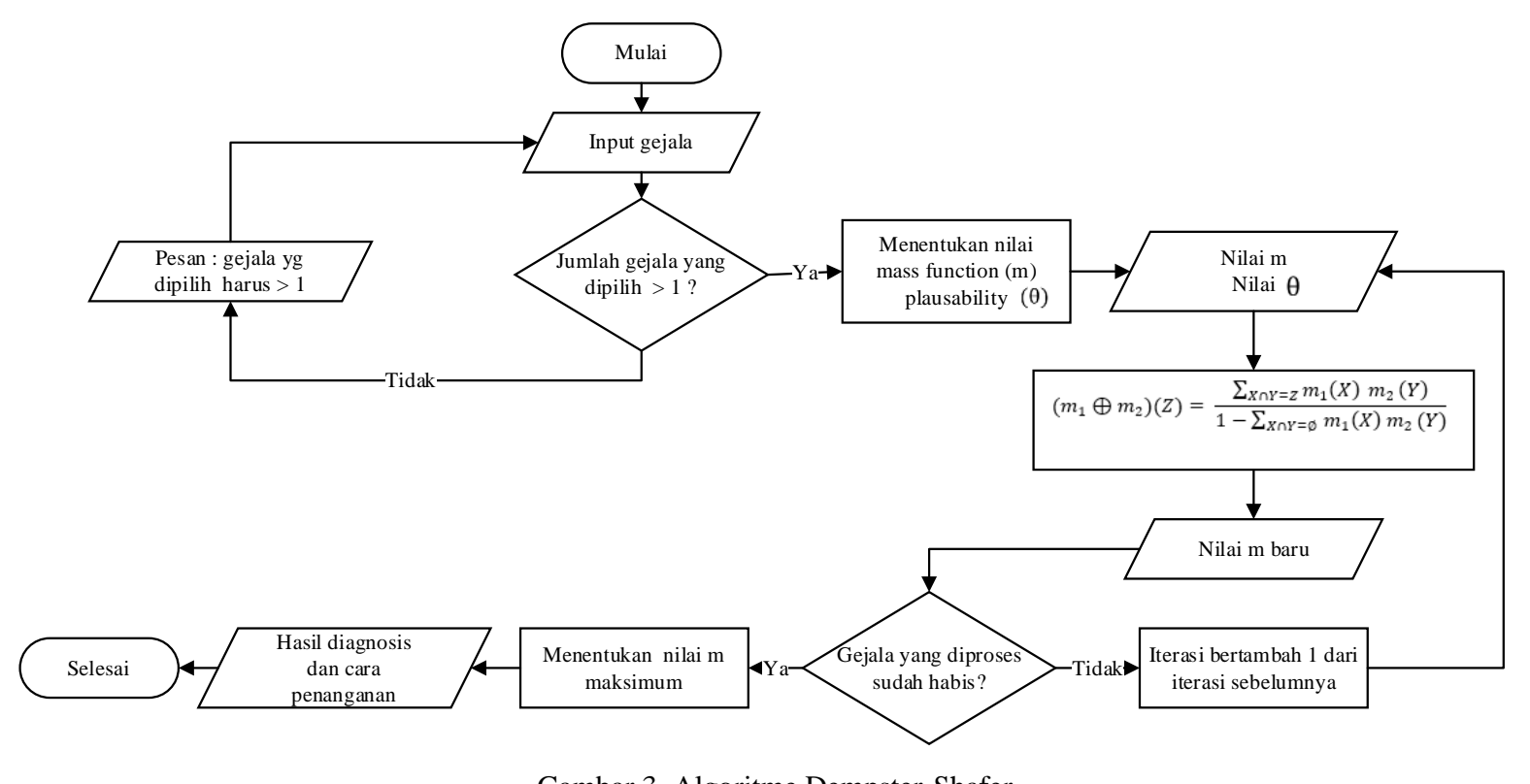

Gambar 3 Algoritme Dempster-Shafer.

Dalam penerapan metode D-S untuk mendiagnosis penyakit atau hama yang menyerang berdasarkan gejala-gejala yang dipilih, maka metode D-S dihitung melalui rumus Dempster's Rule Combination seperti pada Persamaan 2 (Wirawan 2017).

dengan:

$$
\left(m_{1} \oplus m_{2}\right)(Z)=\sum_{X \cap Y=Z} m_{1}(X) m_{2}(Y)
$$

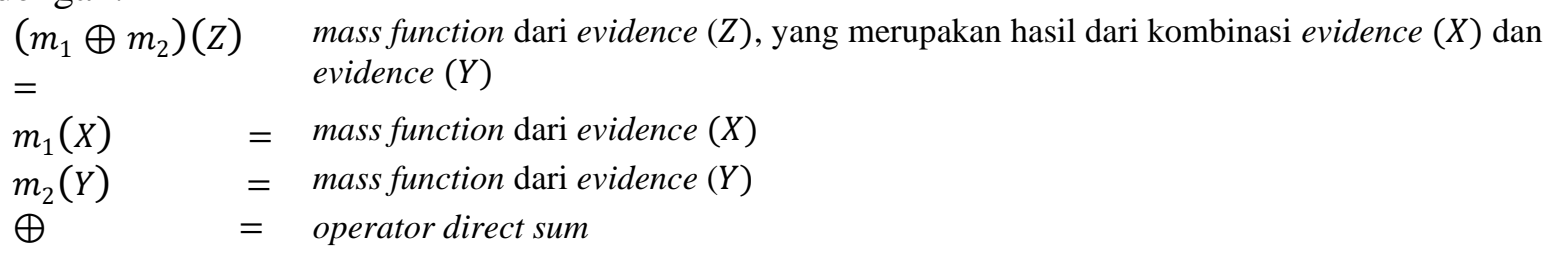

Dalam proses kombinasi memungkinkan terjadi konflik evidence, yaitu ketika melakukan cross product antar evidence menghasilkan elemen himpunan kosong $(\varnothing)$. Untuk mengatasi permasalahan ini diperlukan proses normalisasi evidence dengan mendefinisikan evidential conflict $(k)$ ke dalam Dempster's Rule Combination yang dapat dilihat pada Persamaan 3.

$$
\left(m_{1} \oplus m_{2}\right)(Z)=\frac{\sum_{X \cap Y=Z} m_{1}(X) m_{2}(Y)}{1-\sum_{X \cap Y=\varnothing} m_{1}(X) m_{2}(Y)}
$$

\section{Metode Teorema Bayes}

Mesin inferensi yang digunakan dalam sistem pakar diagnosis penyakit pada tanaman manggis menggunakan metode Teorema Bayes yang alur perhitungannya digambarkan pada Gambar 4. 


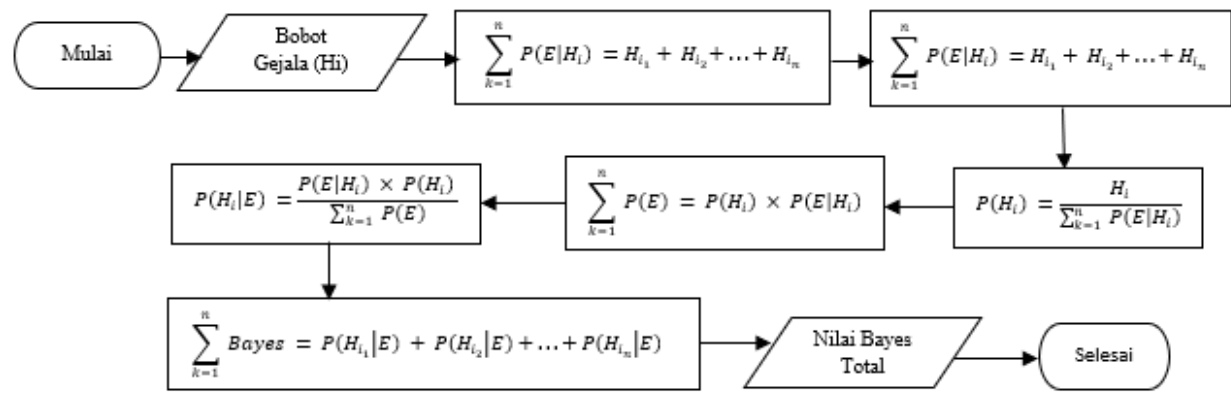

Gambar 4 Algoritme Teorema Bayes.

Keterangan:

$P\left(H_{i} \mid E\right)$

$P\left(E \mid H_{i}\right)$

$P\left(H_{i}\right)$

$n$

: Probabilitas hipotesis $H_{i}$ terjadi jika evidence $E$ terjadi.

: Probabilitas munculnya evidence $E$ jika diketahui hipotesis $H_{i}$ benar.

: Probabilitas hipotesis $H_{i}$ tanpa memandang evidence apapun.

: Jumlah hipotesis yang mungkin.

\section{HASIL DAN PEMBAHASAN}

Berikut adalah contoh tahapan perhitungan untuk mendiagnosis penyakit tanaman manggis serta mengetahui cara penangannya dengan menggunakan metode Case-Based Reasoning, Dempster-Shafer dan Teorema Bayes. Contoh perhitungan ini diambil dari salah satu kasus pada data uji simulasi yang dibuat secara acak.

Misalkan ditemukan beberapa gejala yang timbul pada tanaman manggis, pengguna akan memilih gejala yang timbul sesuai dengan daftar gejala yang telah tersedia pada sistem. Pada contoh ini diambil 3 gejala yang dipilih oleh user yang ditunjukkan pada Tabel 1.

Tabel 1 Contoh gejala yang dipilih pengguna

\begin{tabular}{clc}
\hline No & \multicolumn{1}{c}{ Nama Gejala } & Bobot \\
\hline 1 & Kulit batang terkelupas & 0,8 \\
2 & Terdapat bekas luka gigitan pada buah manggis. & 0,8 \\
3 & Banyak buah yang jatuh atau rontok kepermukaan tanah. & 0,5 \\
\hline
\end{tabular}

\section{Penerapan Metode Case-Based Reasoning}

Selanjutnya dilakukan perhitungan kemiripan antara kasus lama dengan kasus baru seperti pada penjelasan berikut. Pada contoh perhitungan ini terdapat dua kemiripan pada kasus lama.

Tabel 2 Contoh nilai bobot pada kasus lama

\begin{tabular}{clc}
\hline $\begin{array}{c}\text { Nama } \\
\text { Penyakit }\end{array}$ & \multicolumn{1}{c}{ Nama Gejala } & Measure Belief (MB) \\
\hline \multirow{3}{*}{ Babi Hutan } & Tanaman muda akan tumbang. & 0,5 \\
& Perakaran rusak dan daun menjadi layu serta kering. & 0,5 \\
& Pohon lama-kelamaan akan mati. & 0,5 \\
& Kulit batang terkelupas. & 0,8 \\
Tupai & Terdapat bekas luka gigitan pada buah manggis. & 0,8 \\
& Banyak buah yang jatuh atau rontok kepermukaan tanah & 0,5 \\
\hline
\end{tabular}

Kemiripan kasus 1:

$$
\begin{aligned}
\text { Similarity }(\text { problem, case }) & =\frac{(S 1 \times W 1)+(S 2 \times W 2)+\cdots+(S n \times W n)}{W 1+W 2+\cdots+W n} \\
\text { Similarity }(\text { problem }, \text { case }) & =\frac{(1 \times 0,8)+(0 \times 0,8)+(0 \times 0,5)}{0,8+0,8+0,5} \\
& =0,8 / 2,1 \\
& =0,38
\end{aligned}
$$


Kemiripan kasus 2:

$$
\begin{aligned}
\text { Similarity }(\text { problem } \text { case }) & =\frac{(0 \times 0,8)+(1 \times 0,8)+(1 \times 0,5)}{0,8+0,8+0,5} \\
& =1,3 / 2,1 \\
& =0,62
\end{aligned}
$$

Berdasarkan perhitungan pada kasus 1 dan kasus 2, kasus baru memiliki similarity atau kemiripan dengan nilai tertinggi $62 \%$, yaitu pada kasus 2 atau hama tupai, dan memiliki kemiripan dengan kasus 1 atau hama babi hutan dengan nilai $38 \%$.

\section{Penerapan Metode Dempster-Shafer}

Berdasarkan nilai mass function untuk gejala pertama $\left(m_{1}\right)$ dan gejala kedua $\left(m_{2}\right)$ yang dipilih pengguna, mass function baru $\left(m_{3}\right)$ ditentukan melalui perhitungan Dempster's Rule Combination. Proses perhitungan tersebut ditunjukkan pada Tabel 3.

\begin{tabular}{ccc} 
& \multicolumn{2}{c}{ Tabel 3 Perhitungan aturan kombinasi D-S $\left(m_{3}\right)$} \\
\hline & $\boldsymbol{m}_{\mathbf{2}}\{\mathbf{H 0 3}\}=\mathbf{0 . 8}$ & $\boldsymbol{m}_{\mathbf{2}}\{\boldsymbol{\theta}\}=\mathbf{0 . 2}$ \\
\hline $\boldsymbol{m}_{\mathbf{1}}\{\boldsymbol{H 0 2}\}=\mathbf{0 . 8}$ & \{\}$=0.64$ & $\{H 02\}=0.16$ \\
$\boldsymbol{m}_{\mathbf{1}}\{\boldsymbol{\theta}\}=\mathbf{0 . 2}$ & $\{H 03\}=0.16$ & $\{\theta\}=0.04$ \\
\hline
\end{tabular}

$$
\begin{array}{ll}
m_{3}\{\mathrm{H} 02\} & =\frac{0.16}{1-0.64}=0.44 \\
m_{3}\{\mathrm{H} 03\} & =\frac{0.16}{1-0.64}=0.44 \\
m_{3}\{\theta\} & =\frac{0.04}{1-0.64}=0.11
\end{array}
$$

Untuk gejala terakhir yang dipilih, gejala ketiga $\left(m_{4}\right)$ yang dipilih pengguna selanjutnya yaitu menentukan nilai mass function baru $\left(m_{5}\right)$. Proses perhitungan ini dapat dilihat dalam Tabel 4.

Tabel 4 Perhitungan aturan kombinasi D-S $\left(m_{5}\right)$

\begin{tabular}{ccc}
\hline & $\boldsymbol{m}_{\mathbf{4}}\{\boldsymbol{H 0 3}\}=\mathbf{0 . 5}$ & $\boldsymbol{m}_{\mathbf{4}}\{\boldsymbol{\theta}\}=\mathbf{0 . 5}$ \\
\hline $\boldsymbol{m}_{\mathbf{3}}\{\mathbf{H 0 2}\}=\mathbf{0 . 4 4}$ & \{\}$=0.22$ & $\{H 02\}=0.22$ \\
$\boldsymbol{m}_{\mathbf{3}}\{\mathbf{H 0 3}\}=\mathbf{0 . 4 4}$ & $\{\mathrm{H} 03\}=0.22$ & $\{H 03\}=0.22$ \\
$\boldsymbol{m}_{\mathbf{3}}\{\boldsymbol{\theta}\}=\mathbf{0 . 1 1}$ & $\{H 03\}=0.06$ & $\{\theta\}=0.06$ \\
\hline
\end{tabular}

$$
\begin{array}{lll}
m_{5}\{\mathrm{H} 02\} & =\frac{0.22}{1-0.22}=0.2857 \\
m_{5}\{\mathrm{H} 03\} & =\frac{0.22+0.06+0.22}{1-0.22}=0.6429 \\
m_{7}\{\theta\} & =\frac{0.06}{1-0.22}=0.0714
\end{array}
$$

Berdasarkan 3 gejala yang dipilih pengguna didapatkan nilai mass function terbesar yaitu kode penyakit H03. Kode tersebut merupakan kode untuk hama Tupai dengan tingkat kepercayaan sebesar 0.6429 atau dalam persentase sebesar $64.29 \%$.

\section{Penerapan Metode Teorema Bayes}

Pada metode ini pemgguna memilih 3 gejala. Selanjutnya, proses inferensi di setiap gejala yang dipilih akan dilakukan. Proses inferensi untuk gejala pertama dan kedua dapat dilihat pada Tabel 5, sedangkan proses inferensi untuk gejala ketiga dapat dilihat pada Tabel 6.

Tabel 5 Proses perhitungan inferensi hama babi hutan

\begin{tabular}{lc}
\hline \multicolumn{2}{c}{ Hitung Nilai Semesta } \\
\hline Gejala & Bobot \\
[G29] Tanaman muda akan tumbang. & 0.5 \\
\hline
\end{tabular}




\begin{tabular}{|c|c|}
\hline \multicolumn{2}{|l|}{ Hitung Nilai Semesta } \\
\hline [G30] Perakaran rusak dan daun menjadi layu serta kering. & 0.5 \\
\hline [G31] Pohon lama-kelamaan akan mati. & 0.5 \\
\hline [G32] Kulit batang terkelupas. & 0.8 \\
\hline Total Nilai Semesta & 2.3 \\
\hline \multicolumn{2}{|l|}{ Hitung $P\left(H_{i}\right)$} \\
\hline Gejala & Nilai Semesta $P\left(H_{i}\right)$ \\
\hline [G29] Tanaman muda akan tumbang. & $0.5 / 2.3=0.22$ \\
\hline [G30] Perakaran rusak dan daun menjadi layu serta kering. & $0.5 / 2.3=0.22$ \\
\hline [G31] Pohon lama-kelamaan akan mati. & $0.5 / 2.3=0.22$ \\
\hline [G32] Kulit batang terkelupas. & $0.8 / 2.3=0.35$ \\
\hline \multicolumn{2}{|c|}{ Probabilitas $H$ Tanpa Memandang Nilai Apapun } \\
\hline [G29] Tanaman muda akan tumbang. & $0.22 \times 0.5=0.11$ \\
\hline [G30] Perakaran rusak dan daun menjadi layu serta kering. & $0.22 \times 0.5=0.11$ \\
\hline [G31] Pohon lama-kelamaan akan mati. & $0.22 \times 0.5=0.11$ \\
\hline [G32] Kulit batang terkelupas. & $0.35 \times 0.8=0.28$ \\
\hline$\Sigma P\left(H_{i}\right) \times P\left(E \mid H_{i}\right)$ & 0.61 \\
\hline \multicolumn{2}{|l|}{ Mencari nilai $P\left(H_{i} \mid E\right)$} \\
\hline [G29] Tanaman muda akan tumbang. & $0 \times 0 / 0.61=0$ \\
\hline [G30] Perakaran rusak dan daun menjadi layu serta kering. & $0 \times 0 / 0.61=0$ \\
\hline [G31] Pohon lama-kelamaan akan mati. & $0 \times 0 / 0.61=0$ \\
\hline [G32] Kulit batang terkelupas. & $0.8 \times 0.35 / 0.61=0.46$ \\
\hline$\Sigma P\left(H_{i} \mid E\right)$ & 0.46 \\
\hline
\end{tabular}

Tabel 6 Proses perhitungan inferensi hama tupai

\begin{tabular}{lc}
\hline \multicolumn{2}{c}{ Hitung Nilai Semesta } \\
\hline Gejala & Bobot \\
[G33] Terdapat bekas luka gigitan pada buah manggis. & 0.5 \\
[G34] Banyak buah yang jatuh atau rontok kepermukaan tanah. & 0.5 \\
Total Nilai Semesta & 1.3 \\
\hline \multicolumn{1}{c}{ Hitung $P\left(H_{i}\right)$} & Nilai Semesta $P\left(H_{i}\right)$ \\
\hline Gejala & $0.8 / 1.3=0.62$ \\
[G33] Terdapat bekas luka gigitan pada buah manggis. & $0.5 / 1.3=0.38$ \\
[G34] Banyak buah yang jatuh atau rontok kepermukaan tanah. & $0.62 \times 0.8=0.50$ \\
\hline \multicolumn{2}{c}{ Probabilitas $H$ Tanpa Memandang Nilai Apapun } \\
\hline G33] Terdapat bekas luka gigitan pada buah manggis. & $0.38 \times 0.5=0.19$ \\
{$[\mathrm{G} 34]$ Banyak buah yang jatuh atau rontok kepermukaan tanah. } & 0.69 \\
\hline$\Sigma P\left(H_{i}\right) \times P\left(E \mid H_{i}\right) \quad$ Mencari nilai $P\left(H_{i} \mid E\right)$ & $0.8 \times 0.62 / 0.69=0.72$ \\
\hline$[\mathrm{G} 33]$ Terdapat bekas luka gigitan pada buah manggis. & $0.5 \times 0.38 / 0.69=0.19$ \\
{$[\mathrm{G} 34]$ Banyak buah yang jatuh atau rontok kepermukaan tanah. } & 0.99 \\
$\Sigma P\left(H_{i} \mid E\right)$ & \\
\hline
\end{tabular}

Hasil perhitungan data sampel pada proses inferensi di atas dapat dilihat pada Tabel 7.

Tabel 7 Hasil perhitungan data sampel

\begin{tabular}{ccc}
\hline Penyakit dan Hama & Nilai Bayes & Aturan Bayes \\
\hline Hama Babi Hutan & 0.46 & Mungkin \\
Hama Tupai & 0.99 & Pasti \\
\hline
\end{tabular}

Berdasarkan hasil perhitungan yang ditunjukkan pada Tabel 7, nilai Bayes tertinggi adalah 0.99, yaitu Hama Tupai. Selanjutnya, nilai ini dicocokkan dengan aturan Bayes.Nilai 0.99 adalah "Pasti", sehingga diagnosis untuk gejala tersebut adalah Pasti terjangkit Hama Tupai dengan tingkat keyakinan $99 \%$. 


\section{Implementasi}

Hasil implementasi ketiga metode yang digunakan pada penelitian ini dapat dilihat pada Gambar 5, 6, dan 7.

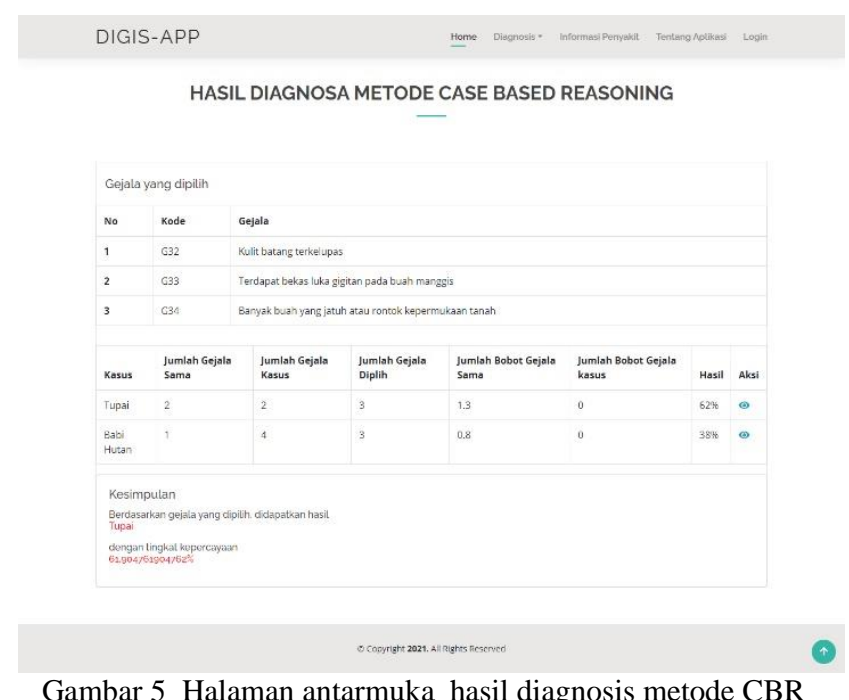

Gambar 5 Halaman antarmuka hasil diagnosis metode CBR
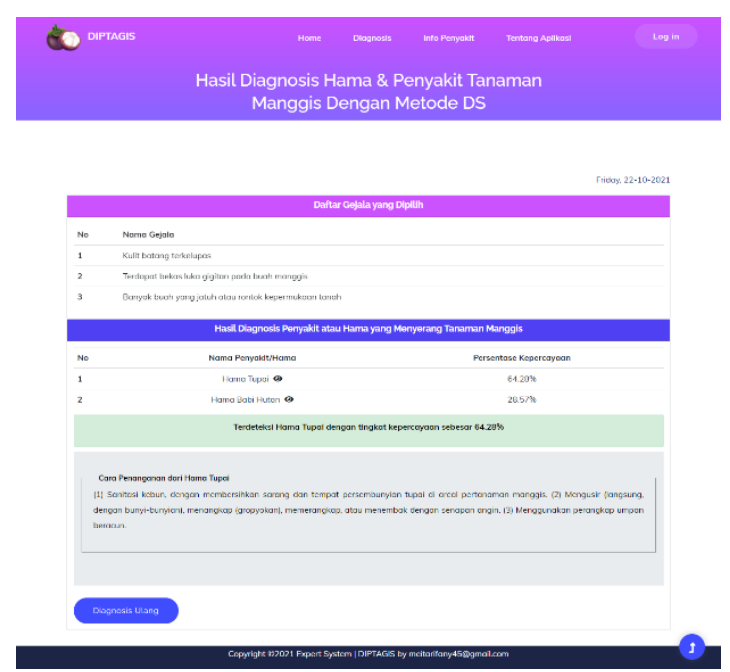

Gambar 6 Halaman Antarmuka Hasil Diagnosis Metode $D-S$.

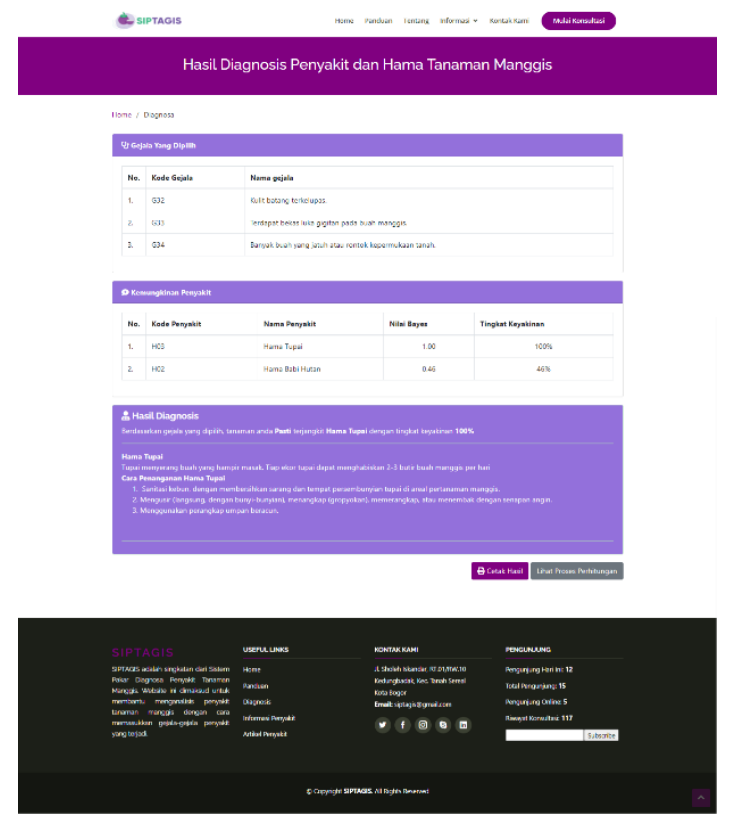

Gambar 7 Halaman antarmuka hasil diagnosis metode Teorema Bayes.

Tabel 8 menunjukkan 30 data uji yang telah dilakukan dengan membandingkan hasil diagnosis sistem untuk ketiga metode yang digunakan pada sistem pakar ini dengan hasil diagnosis pakar. Metode Case-Based Reasoning dan Dempster-Shafer diperoleh 28 data hasil diagnosis yang sesuai dan 2 data hasil diagnosis yang tidak sesuai, sedangkan metode Teorema Bayes mendapatkan 27 data hasil diagnosis yang sesuai dan 3 data hasil diagnosis yang tidak sesuai dengan pakar. Nilai kesesuaian antara diagnosis pakar dan diagnosis sistem menggunakan metode Case-Based Reasoning dan Demspter-Shafer dapat dilihat pada Persamaan 4 dan Persamaan 5.

$$
\begin{aligned}
& \frac{\text { Banyak data sesuai }}{\text { Banyak data uji }} \times 100 \%=\frac{28}{30} \times 100 \%=93 \% \\
& \frac{\text { Banyak data sesuai }}{\text { Banyak data uji }} \times 100 \%=\frac{27}{30} \times 100 \%=90 \%
\end{aligned}
$$


Tabel 8 Hasil evaluasi sistem

\begin{tabular}{|c|c|c|c|c|c|c|c|c|}
\hline \multirow[b]{2}{*}{ No } & \multirow[b]{2}{*}{ Gejala } & \multirow{2}{*}{$\begin{array}{c}\text { Hasil } \\
\text { Diagnosis } \\
\text { Pakar }\end{array}$} & \multicolumn{3}{|c|}{ Hasil Diagnosis Sistem } & \multicolumn{3}{|c|}{ Validasi Sistem } \\
\hline & & & CBR & D-S & $\begin{array}{c}\text { Teorema } \\
\text { Bayes }\end{array}$ & CBR & D-S & $\begin{array}{c}\text { Teorema } \\
\text { Bayes }\end{array}$ \\
\hline 1 & $\mathrm{G} 14, \mathrm{G} 20, \mathrm{G} 21, \mathrm{G} 24$ & $\begin{array}{l}\text { Bercak } \\
\text { Daun }\end{array}$ & $\begin{array}{l}\text { Bercak } \\
\text { Daun }\end{array}$ & $\begin{array}{l}\text { Bercak } \\
\text { Daun }\end{array}$ & $\begin{array}{l}\text { Bercak } \\
\text { Daun }\end{array}$ & Sesuai & Sesuai & Sesuai \\
\hline 2 & G07, G12, G13, G19 & $\begin{array}{l}\text { Kanker } \\
\text { Batang }\end{array}$ & $\begin{array}{l}\text { Kanker } \\
\text { Batang }\end{array}$ & $\begin{array}{l}\text { Kanker } \\
\text { Batang }\end{array}$ & $\begin{array}{l}\text { Kanker } \\
\text { Batang }\end{array}$ & Sesuai & Sesuai & Sesuai \\
\hline 3 & $\begin{array}{l}\text { G02, G11, G21, G22, } \\
\text { G23 }\end{array}$ & $\begin{array}{l}\text { Bercak } \\
\text { Daun }\end{array}$ & $\begin{array}{l}\text { Bercak } \\
\text { Daun }\end{array}$ & $\begin{array}{l}\text { Bercak } \\
\text { Daun }\end{array}$ & $\begin{array}{l}\text { Bercak } \\
\text { Daun }\end{array}$ & Sesuai & Sesuai & Sesuai \\
\hline 4 & $\begin{array}{l}\text { G14, G15, G16, G26, } \\
\text { G28 }\end{array}$ & $\begin{array}{l}\text { Busuk } \\
\text { Akar }\end{array}$ & $\begin{array}{l}\text { Busuk } \\
\text { Akar }\end{array}$ & $\begin{array}{l}\text { Busuk } \\
\text { Akar }\end{array}$ & $\begin{array}{l}\text { Busuk } \\
\text { Akar }\end{array}$ & Sesuai & Sesuai & Sesuai \\
\hline 5 & G33, G36, G37 & $\begin{array}{l}\text { Ulat } \\
\text { pengorok } \\
\text { daun }\end{array}$ & $\begin{array}{l}\text { Ulat } \\
\text { pengorok } \\
\text { daun }\end{array}$ & $\begin{array}{l}\text { Ulat } \\
\text { pengorok } \\
\text { daun }\end{array}$ & Tupai & Sesuai & Sesuai & $\begin{array}{l}\text { Tidak } \\
\text { Sesuai }\end{array}$ \\
\hline 6 & G22, G41, G42 & $\begin{array}{l}\text { Bercak } \\
\text { Daun }\end{array}$ & $\begin{array}{l}\text { Kutu } \\
\text { putih }\end{array}$ & $\begin{array}{l}\text { Kutu } \\
\text { putih }\end{array}$ & $\begin{array}{l}\text { Kutu } \\
\text { putih }\end{array}$ & $\begin{array}{l}\text { Tidak } \\
\text { Sesuai }\end{array}$ & $\begin{array}{l}\text { Tidak } \\
\text { Sesuai }\end{array}$ & $\begin{array}{l}\text { Tidak } \\
\text { Sesuai }\end{array}$ \\
\hline 7 & G03, G04, G05, G09 & $\begin{array}{l}\text { Busuk } \\
\text { Buah }\end{array}$ & $\begin{array}{l}\text { Busuk } \\
\text { Buah }\end{array}$ & $\begin{array}{l}\text { Busuk } \\
\text { Buah }\end{array}$ & $\begin{array}{c}\text { Busuk } \\
\text { Buah }\end{array}$ & Sesuai & Sesuai & Sesuai \\
\hline 8 & $\begin{array}{l}\text { G26, G27, G28, G31, } \\
\text { G32 }\end{array}$ & Thrips & Thrips & Thrips & Thrips & Sesuai & Sesuai & Sesuai \\
\hline 9 & G34, G37, G38, G40 & $\begin{array}{l}\text { Ulat } \\
\text { pengorok } \\
\text { daun }\end{array}$ & $\begin{array}{l}\text { Ulat } \\
\text { pengorok } \\
\text { daun }\end{array}$ & $\begin{array}{l}\text { Ulat } \\
\text { pengorok } \\
\text { daun }\end{array}$ & $\begin{array}{l}\text { Ulat } \\
\text { pengorok } \\
\text { daun }\end{array}$ & Sesuai & Sesuai & Sesuai \\
\hline 10 & $\begin{array}{l}\text { G18, G19, G20, G21, } \\
\text { G23 }\end{array}$ & $\begin{array}{l}\text { Bercak } \\
\text { Daun }\end{array}$ & $\begin{array}{l}\text { Bercak } \\
\text { Daun }\end{array}$ & $\begin{array}{l}\text { Bercak } \\
\text { Daun }\end{array}$ & $\begin{array}{l}\text { Bercak } \\
\text { Daun }\end{array}$ & Sesuai & Sesuai & Sesuai \\
\hline 11 & $\begin{array}{l}\text { G06, G08, G09, G12, } \\
\text { G13, G16 }\end{array}$ & $\begin{array}{l}\text { Kanker } \\
\text { Batang }\end{array}$ & $\begin{array}{l}\text { Kanker } \\
\text { Batang }\end{array}$ & $\begin{array}{l}\text { Kanker } \\
\text { Batang }\end{array}$ & $\begin{array}{l}\text { Kanker } \\
\text { Batang }\end{array}$ & Sesuai & Sesuai & Sesuai \\
\hline 12 & $\mathrm{G} 03, \mathrm{G} 04, \mathrm{G} 05, \mathrm{G} 11$ & $\begin{array}{l}\text { Busuk } \\
\text { Buah }\end{array}$ & $\begin{array}{l}\text { Busuk } \\
\text { Buah }\end{array}$ & $\begin{array}{l}\text { Busuk } \\
\text { Buah }\end{array}$ & $\begin{array}{l}\text { Busuk } \\
\text { Buah }\end{array}$ & Sesuai & Sesuai & Sesuai \\
\hline 13 & G28, G26, G27, G29 & Thrips & Thrips & Thrips & Thrips & Sesuai & Sesuai & Sesuai \\
\hline 14 & $\begin{array}{l}\text { G35, G36, G37, G38, } \\
\text { G41 }\end{array}$ & $\begin{array}{l}\text { Ulat } \\
\text { pengorok } \\
\text { daun }\end{array}$ & $\begin{array}{l}\text { Ulat } \\
\text { pengorok } \\
\text { daun }\end{array}$ & $\begin{array}{l}\text { Ulat } \\
\text { pengorok } \\
\text { daun }\end{array}$ & $\begin{array}{l}\text { Ulat } \\
\text { pengorok } \\
\text { daun }\end{array}$ & Sesuai & Sesuai & Sesuai \\
\hline 15 & $\begin{array}{l}\text { G20, G21, G23, G25, } \\
\text { G16 }\end{array}$ & $\begin{array}{l}\text { Bercak } \\
\text { Daun }\end{array}$ & $\begin{array}{l}\text { Bercak } \\
\text { Daun }\end{array}$ & $\begin{array}{l}\text { Bercak } \\
\text { Daun }\end{array}$ & $\begin{array}{l}\text { Bercak } \\
\text { Daun }\end{array}$ & Sesuai & Sesuai & Sesuai \\
\hline 16 & $\mathrm{G} 01, \mathrm{G} 02, \mathrm{G} 04, \mathrm{G} 05$ & $\begin{array}{l}\text { Busuk } \\
\text { Buah }\end{array}$ & $\begin{array}{l}\text { Busuk } \\
\text { Buah }\end{array}$ & $\begin{array}{l}\text { Busuk } \\
\text { Buah }\end{array}$ & $\begin{array}{l}\text { Busuk } \\
\text { Buah }\end{array}$ & Sesuai & Sesuai & Sesuai \\
\hline 17 & $\begin{array}{l}\text { G17, G29, G30, G31, } \\
\text { G32 }\end{array}$ & Babi Hutan & $\begin{array}{l}\text { Babi } \\
\text { Hutan }\end{array}$ & $\begin{array}{l}\text { Babi } \\
\text { Hutan }\end{array}$ & $\begin{array}{l}\text { Babi } \\
\text { Hutan }\end{array}$ & Sesuai & Sesuai & Sesuai \\
\hline 18 & $\mathrm{G} 14, \mathrm{G} 15, \mathrm{G} 16, \mathrm{G} 17$ & $\begin{array}{l}\text { Busuk } \\
\text { Akar }\end{array}$ & $\begin{array}{l}\text { Busuk } \\
\text { Akar }\end{array}$ & $\begin{array}{l}\text { Busuk } \\
\text { Akar }\end{array}$ & $\begin{array}{l}\text { Busuk } \\
\text { Akar }\end{array}$ & Sesuai & Sesuai & Sesuai \\
\hline 19 & $\begin{array}{l}\text { G14, G15, G16, G12, } \\
\text { G07 }\end{array}$ & $\begin{array}{l}\text { Busuk } \\
\text { Akar }\end{array}$ & $\begin{array}{l}\text { Busuk } \\
\text { Akar }\end{array}$ & $\begin{array}{l}\text { Busuk } \\
\text { Akar }\end{array}$ & $\begin{array}{c}\text { Busuk } \\
\text { Akar }\end{array}$ & Sesuai & Sesuai & Sesuai \\
\hline 20 & $\begin{array}{l}\text { G29, G32, G30, G12, } \\
\text { G31, G11 }\end{array}$ & Babi Hutan & $\begin{array}{l}\text { Babi } \\
\text { Hutan }\end{array}$ & $\begin{array}{l}\text { Babi } \\
\text { Hutan }\end{array}$ & $\begin{array}{c}\text { Babi } \\
\text { Hutan }\end{array}$ & Sesuai & Sesuai & Sesuai \\
\hline 21 & $\begin{array}{l}\text { G22, G23, G24, G25, } \\
\text { G28 }\end{array}$ & $\begin{array}{l}\text { Bercak } \\
\text { daun }\end{array}$ & $\begin{array}{l}\text { Bercak } \\
\text { daun }\end{array}$ & $\begin{array}{l}\text { Bercak } \\
\text { daun }\end{array}$ & $\begin{array}{c}\text { Bercak } \\
\text { daun }\end{array}$ & Sesuai & Sesuai & Sesuai \\
\hline 22 & $\begin{array}{l}\text { G22, G25, G24, G20, } \\
\text { G23, G31 }\end{array}$ & $\begin{array}{l}\text { Bercak } \\
\text { Daun }\end{array}$ & $\begin{array}{l}\text { Bercak } \\
\text { Daun }\end{array}$ & $\begin{array}{l}\text { Bercak } \\
\text { Daun }\end{array}$ & $\begin{array}{l}\text { Bercak } \\
\text { Daun }\end{array}$ & Sesuai & Sesuai & Sesuai \\
\hline 23 & $\begin{array}{l}\text { G08, G12, G06, G40, } \\
\text { G35 }\end{array}$ & $\begin{array}{l}\text { Ulat } \\
\text { penggorok } \\
\text { Daun }\end{array}$ & $\begin{array}{l}\text { Kanker } \\
\text { Batang }\end{array}$ & $\begin{array}{l}\text { Kanker } \\
\text { Batang }\end{array}$ & $\begin{array}{l}\text { Kanker } \\
\text { Batang }\end{array}$ & $\begin{array}{l}\text { Tidak } \\
\text { Sesuai }\end{array}$ & $\begin{array}{l}\text { Tidak } \\
\text { Sesuai }\end{array}$ & $\begin{array}{l}\text { Tidak } \\
\text { Sesuai }\end{array}$ \\
\hline 24 & $\begin{array}{l}\text { G26, G27, G28, G21, } \\
\text { G22 }\end{array}$ & Thrips & Thrips & Thrips & Thrips & Sesuai & Sesuai & Sesuai \\
\hline 25 & G33, G26, G27, G28 & Thrips & Thrips & Thrips & Thrips & Sesuai & Sesuai & Sesuai \\
\hline 26 & $\begin{array}{l}\text { G30, G31, G01, G03, } \\
\text { G04, G05, G12 }\end{array}$ & $\begin{array}{l}\text { Busuk } \\
\text { Buah }\end{array}$ & $\begin{array}{l}\text { Busuk } \\
\text { Buah }\end{array}$ & $\begin{array}{l}\text { Busuk } \\
\text { Buah }\end{array}$ & $\begin{array}{c}\text { Busuk } \\
\text { Buah }\end{array}$ & Sesuai & Sesuai & Sesuai \\
\hline 27 & $\begin{array}{l}\text { G38, G36, G39, G40, } \\
\text { G16 }\end{array}$ & $\begin{array}{l}\text { Ulat } \\
\text { pengorok } \\
\text { daun }\end{array}$ & $\begin{array}{l}\text { Ulat } \\
\text { pengorok } \\
\text { daun }\end{array}$ & $\begin{array}{l}\text { Ulat } \\
\text { pengorok } \\
\text { daun }\end{array}$ & $\begin{array}{l}\text { Ulat } \\
\text { pengorok } \\
\text { daun }\end{array}$ & Sesuai & Sesuai & Sesuai \\
\hline 28 & G30, G31, G32, G40 & Babi Hutan & $\begin{array}{l}\text { Babi } \\
\text { Hutan }\end{array}$ & $\begin{array}{l}\text { Babi } \\
\text { Hutan }\end{array}$ & $\begin{array}{c}\text { Babi } \\
\text { Hutan }\end{array}$ & Sesuai & Sesuai & Sesuai \\
\hline 29 & G03, G04, G05, G08 & $\begin{array}{l}\text { Busuk } \\
\text { Buah }\end{array}$ & $\begin{array}{l}\text { Busuk } \\
\text { Buah }\end{array}$ & $\begin{array}{l}\text { Busuk } \\
\text { Buah }\end{array}$ & $\begin{array}{l}\text { Busuk } \\
\text { Buah }\end{array}$ & Sesuai & Sesuai & Sesuai \\
\hline 30 & G32, G33, G34 & Tupai & Tupai & Tupai & Tupai & Sesuai & Sesuai & Sesuai \\
\hline
\end{tabular}




\section{SIMPULAN}

Penerapan Metode Case-Based Reasoning, Demspter-Shafer, dan Teorema Bayes pada sistem pakar untuk identifikasi hama dan penyakit tanaman manggis berbasis website telah berhasil dibangun. Berdasarkan hasil evaluasi sistem, diperoleh nilai akurasi untuk metode Case-Based Reasoning 93\%, Dempster-Shafer 93\% dan Teorema Bayes 90\%.

\section{DAFTAR PUSTAKA}

Aldo D dan Putra ES. 2020. Sistem pakar diagnosis hama dan penyakit bawang merah menggunakan metode Dempster Shafer. Komputika : Jurnal Sistem Komputer. 9(2):8593.

Hayadi BH. 2016. Sistem Pakar 1 Ed. Yogyakarta (ID): Deepublish.

Jasri M. 2019. Diagnosis hama dan penyakit tanaman bawang merah menggunakan sistem pakar. Journal Of Information System, Graphics, Hospitality And Technology. 1(1): 1519.

Mulyana S. 2009. Tinjauan singkat perkembangan Case-Based Reasoning. Seminar Nasional Informatika 2009 UPN Veteran Yogyakarta. 1(4): 17-24.

Ramadhan PS dan Fatimah U. 2018. Mengenal Metode Sistem Pakar. Ponorogo(ID): Uwais Inspirasi Indonesia.

Saputri AE, Sevani N, Saputra F, Sali RK. 2020. Using certainty factor method to handle uncertain condition in hepatitis diagnosis. ComTech: Computer, Mathematics and Engineering Applications. 11(1): 1-10.

Syah MJA. 2016. Untung Berlipat dari Budi Daya Manggis Tanaman Multi Manfaat. Yogyakarta(ID): Lily Publisher.

Wirawan IMA. 2017. Metode Penalaran dalam Kecerdasan Buatan 1 Ed. Depok(ID): Rajawali Pers. 